\title{
Structural properties of the Ectodomain of Hepatitis C Virus E2 Envelope
}

\section{Protein}

Mar Rodríguez-Rodríguez a, ‡, Daniel Tello ${ }^{\mathrm{a}}$, Belén Yélamos ${ }^{\mathrm{a}}$, Julián Gómez-

Gutiérrez $^{\mathrm{a}}$, Beatriz Pacheco ${ }^{\mathrm{a}}$ §, Sara Ortega ${ }^{\mathrm{a}}$, Alicia G. Serrano ${ }^{\mathrm{a}}$, Darrell L. Peterson ${ }^{\mathrm{b}}$ and Francisco Gavilanes ${ }^{\mathrm{a},}$ *

${ }^{\mathrm{a} D e p a r t a m e n t o ~ d e ~ B i o q u i ́ m i c a ~ y ~ B i o l o g i ́ a ~ M o l e c u l a r, ~ F a c u l t a d ~ d e ~ C i e n c i a s ~ Q u i ́ m i c a s, ~}$

Universidad Complutense, Madrid 28040 and ${ }^{\mathrm{b}}$ Department of Biochemistry and Molecular Biology, Medical College of Virginia, Virginia Commonwealth University, Richmond, Virginia, 23298

* Corresponding author: F. Gavilanes, Departamento de Bioquímica y Biología Molecular, Facultad de Ciencias Químicas, Universidad Complutense, 28040 Madrid, Spain. Phone: (34) 9139442 66. Fax: (34) 9139441 59. E-mail: pacog@bbm1.ucm.es

‡ Present address: Instituto de Química-Física Rocasolano, Consejo Superior de Investigaciones Científicas, 28006 Madrid

${ }^{\S}$ Present address: Department of Cancer Immunology and AIDS, Dana-Farber Cancer Institute, Boston, MA 02115 


\section{Abstract}

We describe the structural and antigenic properties of a soluble form of hepatitis C virus E2 envelope protein ectodomain ending at residue 661 (E2 661$)$ which is obtained in large quantities in a baculovirus/insect cell system. The protein is secreted to the cellular medium by virus-infected cells. E2 661 is glycosylated and possesses a high tendency to self-associate. In fact, analytical ultracentrifugation and size exclusion chromatography studies show that the purified protein is mainly composed of dimers, trimers and tetramers being the dimer the smallest species present in solution. The secondary structure was determined by deconvolution of the far-UV circular dichroism spectrum yielding $8 \% \alpha$-helix structure, $47 \%$ extended structure and $45 \%$ non-ordered structure. The near-UV CD spectrum is indicative of a folded structure. The fluorescence emission spectrum indicates that $\operatorname{Trp}$ residues occupy a relatively low hydrophobic environment. Finally, E2 661 binds to a monoclonal conformation specific antibody and to antibodies present in human sera from HCV-positive patients. All these features suggest that the secreted protein possesses a native-like conformation. The use of this independent folding domain may contribute to shed light on the biology of $\mathrm{HCV}$ and could also be used as a vaccine in the prevention of HCV infection.

Keywords: Hepatitis C Virus, envelope protein, E2, baculovirus, glycosylation 


\section{Introduction}

Hepatitis $\mathrm{C}$ virus (HCV) is an enveloped, positive-stranded RNA virus that belongs to the Hepacivirus genus of the Flaviviridae family (Lindenbach and Rice, 2001). HCV is a major cause of chronic hepatitis, liver cirrhosis, and hepatocellular carcinoma worldwide (Major et al., 2001). There is no vaccine for $\mathrm{HCV}$, and current antiviral therapy is based on the use of polyethylene glycolmodified interferon in combination with ribavirin. However, this treatment is expensive, relatively toxic, and effective in only half of the treated patients (Feld and Hoofnagle, 2005).

HCV encodes two envelope glycoproteins, E1 and E2. They are classified as type I integral transmembrane proteins with an $\mathrm{N}$-terminal ectodomain and a Cterminal hydrophobic domain anchor. The ectodomains contain 5 or 6 and $11 \mathrm{~N}$ glycosylation sites, respectively. During their synthesis, the ectodomains of HCV envelope glycoproteins are targeted to the endoplasmic reticulum lumen, where they are highly modified by N-linked glycosylation (Goffard and Dubuisson, 2003). In vitro expression studies have shown that both glycoproteins associate to form heterodimers, which accumulate in the endoplasmic reticulum, the proposed site for HCV assembly and budding (Op De Beeck et al., 2001).

The E2 glycoprotein extends from amino acid 384 to 746 of the polyprotein from which it derives. The transmembrane domain has been shown to encompass residues 718-746 (Cocquerel et al., 1998) and it has been demonstrated that only polypeptide chains ending before or at residue 661 are properly folded (Michalak et al., 1997). The E2 glycoprotein carries regions of extreme hypervariability (HVR1 and HVR2) (Hijikata et al., 1991; Kato et al., 1992). The most variable region, HVR-1, is located within the N-terminal 27 residues (384- 
1 411) of E2, while HVR-2 resides in the 476-480 fragment. E2 protein has been

2 described to interact with the large extracellular loop of human CD81, its putative

3 cellular receptor (Flint et al., 1999; Owsianka et al., 2001; Pileri et al., 1998). It

4 also elicits production of neutralizing antibodies against the virus, and is involved

5 in viral morphogenesis (Bartosch and Cosset, 2006; Bartosch et al., 2005). The E2

6 protein is considered as a major candidate for anti-HCV vaccine. Antibodies

7 specific for epitopes within HVR-1 have been reported to inhibit binding of E2 to

8 cells and to block HCV infectivity in vitro and in vivo (Habersetzer et al., 1998;

9 Shimizu et al., 1996; Zibert et al., 1999). Despite this, relatively little is known about this protein.

Because of the difficulties in propagating $\mathrm{HCV}$ in cell culture, many aspects of HCV life cycle remain unclear. A major advance in the investigation of $\mathrm{HCV}$ entry was the development of pseudoparticles (HCVpp), consisting of native HCV envelope glycoproteins E1 and E2 assembled into retroviral core particles (Bartosch et al., 2003; Hsu et al., 2003). This system is potentially powerful to identify and characterize molecules that block HCV entry. Furthermore, data obtained with HCVpp can also now be confirmed with the help of the recently developed cell culture system that allows efficient amplification of HCV (Wakita et al., 2005; Zhong et al., 2005).

Previous reports suggest that E1 and E2 interact to form a complex, which has been proposed as a functional subunit of HCV virions (Dubuisson et al., 1994; Ralston et al., 1993). Purified HCV glycoprotein complexes expressed by using vaccinia virus are non-covalently associated. However, in heterologous expression systems, E1 and E2 have a high tendency to form heterogeneous disulfide-linked aggregates, which could represent misfolded complexes (Cocquerel et al., 2003). Knowledge of the three-dimensional structure of $\mathrm{HCV}$ envelope protein E2 will 
1 be of great value in the quest for a vaccine, in explaining existing data and in

2 designing novel experiments. Current understanding of $\mathrm{HCV}$ envelope proteins is

3 based on mammalian cell culture transient expression assays with viral and non-

4 viral vectors. These systems produce very low levels of heterogeneous protein due

5 to glycosylation and aggregation, and it is difficult to distinguish between

6 molecules that undergo productive and non-productive folding (Flint et al., 2000).

7 In the absence of high levels of native E2, some other complexes, such as E1E2

8 glycoproteins reconstituted into liposomes (Lambot et al., 2002) or virus-like

9 particles expressed in insect cell systems (Clayton et al., 2002; Wellnitz et al.,

10 2002), have been used to study virus-cell interactions. In this paper, we describe

11 the cloning, expression and purification of the ectodomain of E2 in a

12 baculovirus/insect cell system, as well as the characterization of its structural and

13 antigenic properties. It behaves as an independent folding domain with native-like

14 properties. Several criteria indicate that it is correctly folded and processed. The

15 protein is secreted to the cell supernatant, it is glycosylated and contains

16 carbohydrates bound at least through N-glycosidic bonds. Furthermore, it self-

17 associates into dimeric and higher order soluble forms which are recognized by a

18 conformation specific antibody and by antibodies present in sera from HCV-

19 positive patients. The structural properties of the recombinant protein derived

20 from circular dichroism and fluorescence spectroscopic studies are described. 


\section{2. Materials and methods}

\subsection{Construction of recombinant transfer vector}

DNA encoding the ectodomain of E2 protein, residues 384-661 (E2661), was inserted into a baculovirus transfer vector pAcGP67A (Pharmingen) with the addition of a six-histidine tag (His tag) immediately $3^{\prime}$ of the multiple cloning site. The cDNA encoding E2 ${ }_{66}$ was obtained by RT-PCR from the viral RNA of a strain 1HCV-PT, genotype 1a, using the following primers:

5'- cgc gga tcc c cat cac cat cac cat cac GAA ACC CAC GTC ACC GGG - 3' (forward)

5'- ggg gaa ttc a CTC GGA CCT GTC CCT GTC - 3' (reverse)

Two restriction sites, BamHI and EcoRI, were created at the $5^{\prime}$ and $3^{\prime}$ ends of E2 ${ }_{661}$ gene, respectively. The amplified reaction product was subcloned into pCR2.1 plasmid (Invitrogen) digested with BamHI and EcoRI. The resulting plasmid was digested with these restriction enzymes and, finally, the E2 $2_{661} \mathrm{cDNA}$ was cloned into the pAcGP67A baculovirus transfer vector downstream of the strong polh promoter to create pAcGP67A-E2 ${ }_{661}$.

\subsection{Insect cell culture and transfections}

The insect cell line Spodoptera frugiperda (Sf9) was cultured in Insect XPress serum-free media (BioWhittaker) at $27^{\circ} \mathrm{C}$. Sf9 cells were cotransfected with Baculogold $^{\mathrm{TM}}$ DNA (Pharmingen) and the recombinant transfer vector pAcGP67A-E2 ${ }_{661}$ as indicated by the manufacturer. Several rounds of culture amplified the recombinant virus, and a high titer virus stock solution was harvested. To express the protein on a larger scale, High Five ${ }^{\mathrm{TM}}$ insect cells 
1 (Invitrogen) were grown in Insect X-Press serum-free media prior to infection

2 with high titer virus $\left(>10^{8} \mathrm{pfu} / \mathrm{ml}\right)$ at a multiplicity of infection of 5-10.

3

$4 \quad$ 2.3. Purification of E2 661

Typically, $500 \mathrm{ml}$ of recombinant baculovirus-infected insect cell cultures were harvested approximately $120 \mathrm{~h}$ postinfection and the cells pelleted by

7 centrifugation at $5000 \mathrm{~g}$ for $10 \mathrm{~min}$. The supernatant was dialyzed against $50 \mathrm{mM}$

8 Tris- $\mathrm{HCl}, \mathrm{pH}$ 8.0, 0.3 $\mathrm{M} \mathrm{NaCl}$ and loaded onto a $\mathrm{Ni}^{2+}$-Nitrilotriacetic acid agarose

9 (Ni-NTA agarose) column (Qiagen) equilibrated with the same buffer. It was then washed with dialysis buffer containing $10 \mathrm{mM}$ imidazole and later $30 \mathrm{mM}$ imidazole. The recombinant $\mathrm{E} 2_{661}$ protein was eluted with $200 \mathrm{mM}$ imidazole in dialysis buffer. The presence of E2 661 was monitored by SDS-PAGE throughout the purification.

\subsection{Protein Deglycosylation}

Protein samples were digested with N-glycosidase F (PNGase F, Roche) for $16 \mathrm{~h}$ at $37^{\circ} \mathrm{C}$ in $20 \mathrm{mM}$ sodium phosphate, $\mathrm{pH}$ 7.0, $50 \mathrm{mM}$ EDTA, and 1\% 
1 (p/v) octylglucoside. Ole e 1 protein was used as a control of deglycosylation (van

2 Ree et al., 2000). Digested samples were mixed with 3X Laemmli sample buffer and analyzed by SDS-PAGE. The proteins were stained with Coomassie brilliant blue $\mathrm{R} 250$ and also transferred to nitrocellulose membranes that were subsequently incubated with the lectin concanavalin A conjugated to biotin (Pierce). The glycoproteins were detected using HRP-streptavidin at a 1:1000 dilution.

\subsection{Mass spectrometry analysis}

The molecular mass of E2 661 was determined by Matrix-Assisted Laser Desorption/Ionization-Time-of-Flight (MALDI-TOF) mass spectroscopy (MS) using a MALDI-TOF Bruker REFLEX IV (Bruker-Francen Analytic GmbH, Bremen, Germany) equipped with reflectron analyzer, delayed extraction capabilities and AutoXecute software for automated spectra acquisition. The matrix was a saturated solution of sinapinic acid (Sigma).

In order to identify $\mathrm{E} 2_{661}$, the protein was digested with trypsin. The resulting peptides were analyzed by MALDI-TOF MS and Surface-Enhanced Laser Desorption/Ionization-Time-of-Flight (SELDI-TOF) MS using a SELDITOF PBS-II mass spectrometer (Ciphergen ProteinChip System). For protein identification, tryptic peptide masses were transferred to BioTools 2.0 interface (Bruker Daltonics) to search in the NCBInr database using Mascot software (www.matrixscience.com; Matrix Science, London, UK).

\subsection{Circular Dichroism}

CD measurements were carried out on a Jasco spectropolarimeter, model J-715. All the measurements were carried out at $25{ }^{\circ} \mathrm{C}$ with cells thermostated 
1 with a Neslab RTE-111 water bath. Far-UV CD and near-UV CD spectra were

2 measured at a protein concentration of $0.15 \mathrm{mg} / \mathrm{ml}$ and $0.5 \mathrm{mg} / \mathrm{ml}$ respectively, 3 using protein dialyzed against $30 \mathrm{mM}$ MOPS, $\mathrm{pH} 7.0,0.1 \mathrm{M} \mathrm{NaCl}$. The 4 pathlengths were 1 and $5 \mathrm{~mm}$, respectively. The contribution of the buffer was

5 always subtracted. The spectra were calculated by using 110 as the mean residue

6 molecular mass and the results are expressed in terms of residue molar ellipticity 7 in $\mathrm{deg} \cdot \mathrm{cm}^{2} \cdot \mathrm{dmol}^{-1}$. The secondary structure of the protein was evaluated by 8 computer fit of the dichroism spectra according to Convex Constraint Analysis

9 (CCA) (Perczel et al., 1991). This method relies on an algorithm that calculates

10 the contribution of the secondary structure elements that give rise to the original

11 spectral curve without referring to spectra from model systems. The secondary structure was also predicted by the GOR IV method (Garnier et al., 1996).

\subsection{Fluorescence spectroscopy}

Emission spectra were obtained at $25^{\circ} \mathrm{C}$ using an SLM AMINCO 8000C spectrofluorimeter. Excitation and emission slit widths were set at $4 \mathrm{~nm}$. The protein concentration was $0.05 \mathrm{mg} / \mathrm{ml}$ and a $0.4 \mathrm{x} 1 \mathrm{~cm}$ cuvette was used. Buffer was $30 \mathrm{mM}$ MOPS, pH 7.0, $100 \mathrm{mM} \mathrm{NaCl}$. Excitation was performed at 275 or $295 \mathrm{~nm}$, and the emission spectra were recorded over the range $285-450 \mathrm{~nm}$. The contribution of the buffer was always subtracted. The tyrosine contribution to the emission spectra was calculated by subtracting the emission spectrum measured at $\lambda_{\text {exc }}=295 \mathrm{~nm}$ multiplied by a factor from that measured at $\lambda_{\text {exc }}=275 \mathrm{~nm}$. The factor was obtained from the ratio between the fluorescence intensities measured with $\lambda_{\text {exc }}=275$ and $\lambda_{\text {exc }}=295 \mathrm{~nm}$ at wavelengths above $380 \mathrm{~nm}$, where there is no tyrosine contribution. 
3 fluorescence quenching experiments with acrylamide and KI were performed at

$425{ }^{\circ} \mathrm{C}$. Protein fluorescence was quenched by the presence of increasing amounts

5 of acrylamide $(0-600 \mathrm{mM})$ or $\mathrm{KI}(0-1 \mathrm{M})$. The KI stock solution also contained

$60.18 \mathrm{M}$ sodium thiosulfate in order to prevent the formation of $I_{3}^{-}$. The

7 fluorescence measurements were determined as continuous emission spectra

8 between 300 and $450 \mathrm{~nm}$ with excitation at $290 \mathrm{~nm}$. The emission spectra were

9 corrected for dilution. The protein concentration was $0.1 \mathrm{mg} / \mathrm{ml}$. Fluorescence intensities at the emission maximum were used for calculations. The fluorescence quenching data were analyzed according to the Stern-Volmer equation:

$$
F_{0} / F=1+K_{S V}[Q]
$$

where $F_{0}$ and $F$ are the fluorescence intensities in the absence and presence of quenchers, respectively, $K_{S V}$ is the collisional Stern-Volmer constant, and [Q] is the quencher concentration. When the plot was not linear, the fluorescence quenching data were analyzed according to the modified Stern-Volmer equation:

$$
\frac{F_{0}}{\left(F_{0}-F\right)}=\frac{1}{f_{a}}+\frac{1}{f_{a} \cdot K_{S V} \cdot[Q]}
$$

where $f_{a}$ is the fraction of fluorescence accessible to the quenching agent (Lehrer, 1971).

\subsection{SDS-PAGE}

Sodium dodecyl sulfate-polyacrylamide gel electrophoresis (SDS-PAGE) was performed according to Laemmli using 15\% polyacrylamide gels (Laemmli, 1970). Samples were subjected to gel electrophoresis under either nonreducing or 
1 reducing conditions (with $5 \%(\mathrm{v} / \mathrm{v}) \beta$-mercaptoethanol) and the proteins were

2 stained with Coomassie brilliant blue R-250. The molecular mass of the protein

3 bands was estimated by comparison with protein markers of known molecular mass (Prestained SDS-PAGE Standards, Bio-Rad).

$6 \quad$ 2.11. Western blotting

After SDS-PAGE, proteins were transferred to nitrocellulose membranes

8 (Hybond-ECL; Amersham) in $48 \mathrm{mM}$ Tris/HCl, $\mathrm{pH} 9.0$, containing $39 \mathrm{mM}$

9 glycine, $0.0375 \%$ SDS and $20 \%(\mathrm{v} / \mathrm{v})$ methanol, for $1 \mathrm{~h}$ at $1 \mathrm{~mA} / \mathrm{cm}^{2}$, by using a

10 V20-SDB apparatus (Scie-Plas). To detect E2 ${ }_{661}$, membranes were incubated with

11 a HRP-conjugated monoclonal anti-His (Sigma) at a 1:3000 dilution. The

12 peroxidase reaction was developed with 3, 3'-diaminobenzidine

\subsection{Analytical ultracentrifugation}

The sedimentation velocity experiments were carried out on a Beckman Optima XL-A analytical ultracentrifuge equipped with UV-VIS optics detection system, using an An60Ti rotor and $12 \mathrm{~mm}$ double-sector centerpieces. The experiments were performed at $20^{\circ} \mathrm{C}$ with a protein concentration of $5 \mu \mathrm{M}$. The buffer employed was $50 \mathrm{mM}$ Tris-HCl, $300 \mathrm{mM} \mathrm{NaCl}$, pH 7.0. The sedimentation 
1 coefficient distributions were calculated by modelling of the sedimentation

2 velocity data using the $c(s)$ method (Schuck, 2000), as implemented in the

3 SEDFIT program, from which the corresponding sedimentation coefficients (s-

4 values) were obtained.

\subsection{Size Exclusion Chromatography}

The purified E2 661 was chromatographed on a FPLC (Pharmacia) system by using a Superdex G-200 column equilibrated with $50 \mathrm{mM}$ Tris- $\mathrm{HCl}, 300 \mathrm{mM}$ $\mathrm{NaCl}, \mathrm{pH} 8.0$. The separation was monitored at $280 \mathrm{~nm}$. The elution volume of each peak was compared with that of molecular mass markers.

\subsection{Enzyme Linked Immunosorbent Assay (ELISA)}

96 wells microtitre plates (Costar 3690) were coated overnight at $4{ }^{\circ} \mathrm{C}$ with $100 \mathrm{ng} /$ well of purified recombinant E2 ${ }_{661}$ diluted to $1 \mu \mathrm{g} / \mathrm{ml}$ in $0.05 \mathrm{M}$ carbonatebicarbonate buffer, $\mathrm{pH}$ 9.6. Unbound antigen was discarded, and the wells were blocked with 3\% non-fat dry milk in PBS for 60 min at room temperature. After washing, the wells were incubated at $37^{\circ} \mathrm{C}$ for $2 \mathrm{~h}$ with human serum. Eight $\mathrm{HCV}$ positive human sera and ten $\mathrm{HCV}$-negative human sera were used at a dilution of 1:200. The plates were washed three times with PBS/0.05\% Tween 20 and incubated at $37^{\circ} \mathrm{C}$ for $1 \mathrm{~h}$ with HRP-conjugated anti-human $\mathrm{IgG}(\mathrm{Fc})$ diluted at 1:10.000. Bound antibodies were detected by adding $100 \mathrm{mM}$ sodium citrate, $\mathrm{pH}$ 5.0, 4\% Methanol buffer containing $\mathrm{H}_{2} \mathrm{O}_{2}$ and the substrate o-phenylenediamine dihydrochloride (Merck). The optical density at $492 \mathrm{~nm}$ was measured using an ELISA Expert 96 microplate reader (ASYS Hitech). Sera from infected and control patients were provided by Dr. Fernando Vivanco (Fundación Jiménez Díaz, Madrid, Spain). 

9 three times with this buffer and once with distilled water. The precipitates were then

\subsection{Immunoprecipitation}

A $50 \mu 1$ aliquot of rabbit anti-mouse immunoglobulin $\mathrm{G}$ bound to Sepharose beads (Pharmacia-LKB) was incubated with $2 \mu$ of anti-E2 monoclonal antibody $\mathrm{H} 53$ or $2 \mu \mathrm{l}$ of rabbit serum for $1 \mathrm{~h}$ at $4{ }^{\circ} \mathrm{C}$ in $10 \mathrm{mM}$ Tris-Cl, $\mathrm{pH} 7.5$, containing $0.2 \% \mathrm{NP}-40,150 \mathrm{mM} \mathrm{NaCl}$ and $2 \mathrm{mM}$ EDTA (TBS-NP-40). The MAb H53 is conformation-dependent and was a generous gift of Dr. Jean Dubuisson. Beads were

then incubated with $2 \mu \mathrm{g}$ of purified $\mathrm{E} 2_{661}$ for $1 \mathrm{~h}$ at $4^{\circ} \mathrm{C}$. Between each step, the beads were washed twice with TBS-NP-40. After the last step, they were washed boiled for $5 \mathrm{~min}$ in SDS-PAGE sample buffer and analyzed on a $12 \%$ 1 polyacrylamide gel. After electrophoresis and transfer to nitrocellulose membranes, 2 protein $\mathrm{E} 2{ }_{661}$ was detected by incubating the membranes with a polyclonal goat antiE2 antibody (USBiological) at a 1:500 dilution followed with a rabbit anti-goat antibody conjugated to HRP diluted at 1:3000. The peroxidase reaction was developed with 3,3'-diaminobenzidine tetrahydrochloride $/ \mathrm{H}_{2} \mathrm{O}_{2}$. 


\section{3. Results and Discussion}

Previous attempts have been made to obtain either full length E2 or E2 ectodomain. Expression of E2 ${ }_{661}$ in Escherichia coli led to the production of inclusion bodies which were solubilized with chaotropic agents. The nonglycosylated recombinant protein thus obtained was able to interact with the virus receptor CD81 and it was recognized by a number of anti-E2 antibodies (Hüssy et al., 1997; Xiang et al., 2006; Yurkova et al., 2004). The fact that E2 ${ }_{661}$ produced in E. coli is insoluble, points to glycosylation as an indispensable factor for the global folding of E2. In fact, it has been reported that the glycans of HCV envelope glycoproteins play a major role in protein folding and/or in HCV entry (Dubuisson and Rice, 1996; Goffard et al., 2005; Helenius and Aebi, 2001). The glycosylation also modulates the neutralizing activity of anti-HCV antibodies. At least three glycans in positions N1, N6 and N11 of E2 reduce the sensitivity of HCV pseudoparticles to antibody neutralization (Helle et al., 2007). In contrast, the glycosylation does not seem to be necessary for the binding to its receptor CD81 (Xiang et al., 2006; Yurkova et al., 2004).

The HCV structural E2 protein has also been produced in mammalian expression systems (Owsianka et al., 2001; Patel et al., 2000) and yeast cells (Martinez-Donato et al., 2006). In all cases, the majority of the secreted E2 661 exhibited a molecular mass much higher than that expected because of the hyperglycosylation of the protein. Moreover, the levels of expression are so low that the recombinant proteins can only be used to detect $\mathrm{HCV}$-specific antibodies in human sera. The expression of different polypeptide forms of E2 in recombinant baculovirus-infected insect or human hepatoma cells has also been 
1 reported although no structural information is given (Cerino et al., 1997; Hsu et

2 al., 1993; Hüssy et al., 1997; Hüssy et al., 1996; Matsuo et al., 2006; Matsuura et

3 al., 1992). Thus, by using different recombinant constructs containing the E2

4 protein terminating at residue 662, several E2 related proteins were observed (Hsu

5 et al., 1993). These were partially purified by cutting the protein bands from

6 preparative SDS-PAGE and electroeluting them in PAGE running buffer. Their

7 immunoreactivity was tested using sera from patients chronically infected with

$8 \mathrm{HCV}$ and only $10 \%$ reacted with the E2 protein (Hsu et al., 1993). On the other

9 hand, a protein comprising residues $406-660$ of E2 was secreted by Sf9 cells

10 infected with recombinant baculovirus. The protein was purified under native

11 conditions and used to show that it was glycosylated and that it reacted with

12 antibodies from $\mathrm{HCV}$-seropositive patients (Hüssy et al., 1996). Finally, a

13 truncated soluble E2 protein, spanning residues 390-683, expressed in insect cells

14 using a baculovirus vector was purified under native conditions from the culture

15 supernatant. It was used to study the human antibody response to HCV infection

16 (Cerino et al., 1997).

17 We describe herein the expression and purification of large quantities of a 18 soluble form of E2 ectodomain (E2 $\left.{ }_{661}\right)$ which has allowed us to determine its 19 structural and antigenic properties. To overcome the hyperglycosilation problems encountered in yeast, we have expressed E2 661 protein using a baculovirus expression system. 6x His tag, the gene was first cloned into the pAcGP67A transfer vector that uses

\subsection{Expression and purification of $E 2_{661}$ from High Five ${ }^{T M}$ cells}

To produce the recombinant virus that expresses the $\mathrm{E} 2_{661}$ protein with a the gp67 secretory sequence of the baculovirus envelope protein. Next, the 
1 recombinant vector was transfected along with wild-type viral DNA into Sf9 cells

2 and in a homologous recombination event, the E2 661 gene was inserted into the

3 viral genome. The protein was expressed by infecting a new batch of insect cells

4 using amplified recombinant virus. Cells were grown and protocols were carried

$5 \quad$ out as described in Materials and methods.

Recombinant E2 661 would have 287 amino acids, 278 corresponding to positions 384 to 661 of $\mathrm{E} 2$ and 9 extra amino acids at the $\mathrm{N}$-terminal end, the sequence ADP due to cloning plus the $6 x$ His. After $48 \mathrm{~h}$ post-infection, virusinfected cells produced several proteins which were recognized by an anti-His antibody, a major one with a molecular mass of $50 \mathrm{kDa}$ and other minors that could correspond to less glycosylated products and/or polypeptide chains truncated at their C-terminal (data not shown). Of all these proteins, a single one with a molecular mass of about $48 \mathrm{kDa}$ was partially $(60 \%)$ secreted to the cell supernatant.

When High Five ${ }^{\mathrm{TM}}$ cells were infected, this protein was almost completely secreted to the extracellular medium. The accumulated amount of secreted protein was monitored directly at various post-infection times by Western blot analysis (data not shown). The highest amount was obtained 5 days post-infection. From day 5 , the amount decreased because insect cell lysosomal proteases were released from lysed cells.

The protein secreted to the extracellular medium was purified by a NiNTA-agarose column as described in Materials and methods. The fractions eluted with $200 \mathrm{mM}$ imidazole contained a protein which behaves as a single band in SDS-PAGE with a molecular mass of $48.3 \mathrm{kDa}$ (Fig. 1, lane 1). Its purity was assessed to be higher than $95 \%$ in the presence of reducing agents (Fig. 1, lane 1). The yield of the process was 5-6 mg of protein per liter of media. The molecular 
1 mass of the purified protein is similar to that provided by other authors when

2 E2 ${ }_{661}$ is obtained by transient expression in mammalian cells (Flint et al., 2000).

\subsection{Biochemical characterization of $E 2_{661}$}

Several studies indicated that the secreted protein was indeed E2 ${ }_{661}$. When analyzed by UV spectroscopy, purified E2 661 gave an absorption spectrum

7 characteristic of a soluble protein. It exhibited a maximum at $278 \mathrm{~nm}$ and a 8 shoulder at $290 \mathrm{~nm}$ (data not shown). A value of 2.73 for $E^{0.1 \%}$ at $280 \mathrm{~nm}$ was 9 experimentally calculated. This specified extinction coefficient together with the absorbance at $280 \mathrm{~nm}$ were used to determine the protein concentration in all subsequent experiments. The amino acid composition of the recombinant protein was determined by amino acid analysis, being almost identical to that predicted from the DNA sequence. On the other hand, the Edman degradation of purified 
1 it seems clear that the isolated protein really corresponds to the ectodomain of E2.

2 On the other hand, the fact that the peptides containing the Cys residues 55, 223,

$3233,246,270$ and 278 are observed in the non-reduced sample, would indicate

4 that at least 6 out of the 17 cysteines of E2 ectodomain are not forming inter or

5 intramolecular disulphide bridges.

6

SDS-PAGE in the presence of reducing agents showed a single band at $48.3 \mathrm{kDa}$ that could correspond to the monomer (Fig. 1, lane 1). However, in the absence of reducing agents four main bands were observed (Fig. 1, lane 2). These have molecular masses that could correspond to monomeric, dimeric, trimeric and tetrameric forms of $\mathrm{E} 2{ }_{661}$. Also, higher order structures which do not enter the gel were observed. Therefore, E2 661 would tend to self-associate through hydrophobic interactions and/or disulfide bridges. Mass spectrometry analysis of the intact protein confirmed the oligomeric nature of E2 ${ }_{661}$. MALDI-TOF yielded four peaks with molecular masses of $43.4,81.1,121.1$ and $160.8 \mathrm{kDa}$ (data not shown), which could also correspond to the same species observed by SDS-PAGE. The lower mass of the dimer, trimer and tetramer, as expected from that of the monomer, $43.4 \mathrm{kDa}$, could be due to the fact that the spectrometer is calibrated at the mass of the monomer and the error for the massess of the high order structures is considerable higher. On the other hand, the difference between the molecular mass values obtained by MS and electrophoresis could be due to the presence of the $6 \mathrm{x}$ His tag which promotes a lower migration on SDS-PAGE.

The oligomeric nature of E2 $2_{661}$ was also assessed by analytical ultracentrifugation. Sedimentation equilibrium experiments showed that the soluble protein was present as a mixture of molecular species. The polydispersity of the protein prompted us to use sedimentation velocity to determine the nature of the main species present in solution. Using this method, the presence of several 
1 oligomeric species of E2 661 was detected (Fig. 2). The calculated molecular mass

2 of the most abundant species was $96 \pm 12 \mathrm{kDa}$ with a sedimentation coefficient of

$34.3 \mathrm{~S}$. Considering that the molecular mass of the E2 ${ }_{661}$ monomer determined by

4 SDS-PAGE is $48.3 \mathrm{kDa}$, the major form found by analytical ultracentrifugation is

5 compatible with a dimer. The area under the peaks allowed us to estimate that the

6 dimer accounts for $30-40 \%$ of the total species present. The sedimentation

7 coefficients of the other molecular forms observed are compatible with tetramers

8 (20\%), hexamers (15\%) and higher forms (25\%). A similar behaviour was

9 observed when the purified protein was chromatographed on a Superdex G-200

10 FPLC column. Moreover, when the peak which eluted at the dimer volume was

11 subjected to SDS-PAGE in the absence of reducing agents, only a band with the molecular mass of the monomer was observed (data not shown).

Therefore, as indicated by sedimentation velocity and size exclusion

chromatography experiments, E2 ${ }_{661}$ has a high tendency to self-assocciate, being the dimer the smallest form present. The presence of dimers had also been 
1 reducing agent tris-(2-carboxyethyl)-phosphine (data not shown). Thus, as

2 previously proposed, the high tendency to form oligomers must be just an intrinsic 3 property of E2 sequence (Dubuisson, 2000).

On the other hand, as mentioned above, E2 is predicted to contain several

5 glycosylation sites (Goffard and Dubuisson, 2003). A global sequence analysis

6 indicates that it has 11 potential glycosylation sites, most of which are well-

7 conserved (Goffard and Dubuisson, 2003; Helle et al., 2007; Zhang et al., 2004a;

8 Zhang et al., 2004b). The purified E2 ${ }_{661}$ behaves in SDS-PAGE in the presence of

9 reducing agents as a single band with a molecular mass of $48.3 \mathrm{kDa}$ while the

10 theoretical mass based on the amino acid sequence is $31.65 \mathrm{kDa}$. Therefore, $\mathrm{E} 2_{661}$

11 must be glycosylated. In fact, $\mathrm{E} 2_{661}$ is recognized by concanavalin A (Fig. 3B,

12 lane 1). Moreover, the enzymatic deglycosylation with PNGase, which removes carbohydrates bound through N-glycosydic bonds, rendered a double band at 35-

\subsection{Spectroscopic analysis of E2 661}

The spectroscopic characterization of $\mathrm{E} 2{ }_{661}$ was carried out by means of circular dichroism and fluorescence spectroscopy. Far-UV CD spectrum of E2 661 showed a minimum at 207 (Fig. 4A), indicative of a high percentage of nonregular structure. This spectrum is maintained in the presence of a $1 \mathrm{mM}$ 
1 concentration of the reducing agent tris-(2-carboxyethyl)-phosphine.

2 Deconvolution of this spectrum using the program Convex Constraint Analysis

3 (CCA) (Perczel et al., 1991) yielded the percentages of secondary structure given

4 in Table 2. The predictive GOR IV method (Garnier et al., 1996), which is based

5 upon the propensity of each amino acid to adopt a particular secondary structure,

6 also indicates that helical structures are almost absent and that the main ordered

7 structures are $\beta$-sheets (Table 2). The near-UV CD spectrum of $E 2_{661}$ has two

8 minima at 268 and $300 \mathrm{~nm}$ whose ellipticity values were -37 and -30

9 degree $\cdot \mathrm{cm}^{2} \cdot \mathrm{dmol}^{-1}$, respectively (Fig. 4B). These two dichroic bands reveal the

10 asymmetric nature of the microenvironment of Trp and Tyr residues and, hence,

11 the folded character of the purified protein.

The fluorescence emission spectrum of E2 ${ }_{661}$ showed a maximum at 334

nm (Fig. 5), which is typical of Trp residues in relatively low hydrophobic

environments. The shape of the spectrum indicates that Tyr fluorescence is quenched by near residues or by energy transfer to Trp residues. The difference between the fluorescence spectra obtained upon excitation at 275 and $295 \mathrm{~nm}$ provides the low contribution of Tyr residues to the protein fluorescence (Fig. 5). 
1 E2 661 fluorescence by iodide was linear up to $0.4 \mathrm{M}$, with a marked upward

2 curvature above this concentration (data not shown). At iodide concentrations 3 higher than $0.4 \mathrm{M}$ the maximum of the emission spectrum undergoes a red shift 4 which indicates that the protein is denatured, with two populations of $\operatorname{Trp}$

5 residues, accessible and non-accessible to iodide. Moreover, the population of

6 fluorophores accessible to quencher is homogeneous, since when quenching of

7 E2 661 fluorescence data were plotted according to the modified Stern-Volmer 8 relationship, a linear plot was observed (Fig. 6). The value of $f_{a}=0.83$ calculated

9 from this plot indicates that eight of the ten Trp residues were accessible to 10 iodide. The low value of $K_{S V}, 5.2 \mathrm{M}^{-1}$, indicated that the accessible Trp residues 11 are not at the surface since $K_{S V}$ would otherwise be higher ( $K_{S V}$ for free N-acetyl-

12 L-tryptophanamide in aqueous solution is $17.5 \mathrm{M}^{-1}$ ) (Lehrer, 1971). Taken 13 together, all these results indicate that $\mathrm{E} 2{ }_{661}$ recombinant protein has a somehow open conformation, but different from a denatured state.

\subsection{Antigenic properties of $E 2_{661}$}

A panel of eight $\mathrm{HCV}$-positive human sera and ten $\mathrm{HCV}$-negative human sera was used to assess the antigenic properties of the E2 661 recombinant protein. All sera were tested by ELISA for E2-specific antibodies as described in Material and methods. E2 661 recombinant protein was able to bind to antibodies present in all HCV-positive human sera at a dilution of 1:200. The optical density values reached with the positive sera (Fig. 7, sera 1-8) were much higher than those of the negative controls (Fig. 7, sera 9 and 10; only two of the ten negative sera are depicted). The observed differences in the value of the optical density at $492 \mathrm{~nm}$ are consistent with the HCV titer as determined by COBAS TaqMan HCV test (Hu et al., 2005) (data not shown). 
The structural properties of the different epitopes were assessed by Western blot analysis. The effect of the denaturation with SDS and $\beta$ mercaptoethanol on the reactivity of E2 against the human sera was tested. As depicted in Fig. 7, sera 1, 2, 3, 4 and 8 reacted to a different extent with denatured and reduced E2 661 while sera 5, 6 and 7 gave almost no reaction (Fig. 7). This suggests that some of the antibodies present in HCV-positive human sera bind to conformation-dependent epitopes. Therefore, E2 661 should contain both continuous and discontinuous antigenic determinants. Reduction would destroy the antigenic reactivity of discontinuous epitopes thus indicating the role of disulfide bridges in stabilizing their conformation.

Finally, the conformation of E2 661 was examined by immunoprecipitation with an anti-E2 conformation-dependent monoclonal antibody, H53. The E2 661 protein was efficiently immunoprecipitated by the antibody, suggesting that the purified protein possesses a native-like conformation. Moreover, all the oligomeric forms were able to react with the antibody.

HCV envelope glycoproteins, E1 and E2, have been shown to form noncovalent heterodimers as well as heterogeneous disulfide-linked aggregates (Dubuisson et al., 1994; Ralston et al., 1993). Characterization of the noncovalent heterodimer with conformation dependent monoclonal antibodies has suggested that this oligomer is likely the prebudding form of the functional complex (Deleersnyder et al., 1997). Michalak and coworkers (1997) have shown that the folding of E1 is helped by the coexpression of E2 (Michalak et al., 1997). Moreover, two earlier studies indicate that HCV envelope glycoproteins cooperate for the formation of a functional complex and that both glycoproteins have to be co-expressed to analyze their functional properties (Brazzoli et al., 2005; 
1 Cocquerel et al., 2003). Taking into account the results described in this paper it

2 seems reasonable to asume that $\mathrm{E} 2{ }_{661}$ recombinant protein is folded in a native

3 conformation and presents antigenic properties similar to E2 assembled in the

4 HCV virion. Therefore, E2 ectodomain would not need the presence of E1 to

5 achieve its native structure, it represents the structural core of functional E2, and it

6 behaves as an independent folding domain. Now that high levels of properly

7 folded $\mathrm{E} 2_{661}$ can be obtained, further studies of its three-dimensional structure as

8 well as its role in receptor binding and in the fusion mechanism of the HCV can

9 be carried out. Also, and since E2 ${ }_{661}$ containing different sequences of the HVR1

10 can be obtained (M. Rodríguez-Rodríguez and F. Gavilanes, unpublished data), a

11 mixture of polypeptide chains corresponding to the ectodomain of E2 envelope

12 protein could be used as a vaccine in the prevention of $\mathrm{HCV}$ infection. 


\section{Acknowledgments}

2

3

This work was supported by grant BFU 2006-13033 from the Ministerio de

4 Educación y Ciencia, Spain. M.R.R. was funded by a fellowship from the Ministerio

5 de Educación y Ciencia, Spain. Authors greatfully acknowledge Dr. J. Pérez-Gil

6 (Universidad Complutense) for his assistance with the baculovirus expression

7 system, Dr. Juan P. Albar (Centro Nacional de Biotecnología) for the mass

8 spectrometry analysis, Dr. German Rivas for the analytical ultracentrifugation

9 analysis and Dr. Jean Dubuisson for kindly providing the monoclonal antibody H53. 


\section{$1 \quad$ References}

2 Bartosch, B.,Cosset, F.L., 2006. Cell entry of hepatitis C virus. Virology 348, 1-12.

3 Bartosch, B., Dubuisson, J.,Cosset, F.L., 2003. Infectious hepatitis C virus pseudoparticles containing functional E1-E2 envelope protein complexes. J. Exper. Med. 197, 633-642.

Bartosch, B., Verney, G., Dreux, M., Donot, P., Morice, Y., Penin, F., Pawlotsky, J.M., Lavillette, D.,Cosset, F.L., 2005. An interplay between hypervariable region 1 of the Hepatitis C Virus E2 glycoprotein, the scavenger receptor BI, and high-density lipoprotein promotes both enhancement of infection and protection against neutralizing antibodies. J. Virol. 79, 8217-8229.

Brazzoli, M., Helenius, A., Foung, S.K.H., Houghton, M., Abrignani, S.,Merola, M., 2005. Folding and dimerization of hepatitis C virus E1 and E2 glycoproteins in stably transfected CHO cells. Virology 332, 438-453.

Cerino, A., Bissolati, M., Cividini, A., Nicosia, A., Esumi, M., Hayashi, N., Mizuno, K., Slobbe, R., Oudshoorn, P., Silini, E., Asti, M.,Mondelli, M.U., 1997. Antibody responses to the hepatitis $\mathrm{C}$ virus $\mathrm{E} 2$ protein: relationship to viraemia and prevalence in anti-HCV seronegative subjects. J Med Virol 51, $1-5$.

Clayton, R.F., Owsianka, A., Aitken, J., Graham, S., Bhella, D.,Patel, A.H., 2002. Analysis of antigenicity and topology of E2 glycoprotein present on recombinant hepatitis C virus-like particles. J. Virol. 76, 7672-7682.

Cocquerel, L., Meunier, J.C., Pillez, A., Wychowsky, C.,Dubuisson, J., 1998. A retention signal necessary and sufficient for endoplasmic reticulum localization maps to the transmembrane domain of hepatitis $\mathrm{C}$ virus glycoprotein E2. J. Virol. 72, 2183-2191. 
1 Cocquerel, L., Quinn, E.R., Flint, M., Hadlock, K.G., Foung, S.K.H.,Levy, S., 2003. Recognition of native hepatitis $\mathrm{C}$ virus E1E2 heterodimers by a human monoclonal antibody. J. Virol. 77, 1604-1609.

Deleersnyder, V., Pillez, A., Wychowski, C., Blight, K., Xu, J., Hahn, Y.S., Rice, C.M.,Dubuisson, J., 1997. Formation of native hepatitis C virus glycoprotein complexes. J.Virol. 71, 697-704.

Dubuisson, J., 2000. Folding, Assembly and subcellular localization of hepatitis C virus glycoproteins, in: C.J. Hagedorn and C.M. Rice (Eds), Current topics in microbiology and immunology, Vol. 242.pp. 135-148.

Dubuisson, J., Hsu, H.H., Cheung, R.C., Greengberg, H.C., Russell, D.G.,Rice, C.M., 1994. Formation and intracellular localization of hepatitis C virus enveloped glycoprotein complexes expressed by recombinant vaccinia and sindbis viruses. J. Virol. 68, 6148-6160.

Dubuisson, J.,Rice, C.M., 1996. Hepatitis C virus glycoprotein folding: disulfide bond formation and association with calnexin. J. Virol. 70, 778-86.

Feld, J.J.,Hoofnagle, J.H., 2005. Mechanism of action of interferon and ribavirin in treatment of hepatitis C. Nature 436, 967-972.

Flint, M., Dubuisson, J., Maidens, C., Harrop, R., Guile, G.R., Borrow, P.,McKeating, J.A., 2000. Functional characterization of intracellular and secreted forms of a truncated hepatitis C virus E2 glycoprotein. J. Virol. 74, 702-709.

Flint, M., Maidens, C., Loomis-Price, L.D., Shotton, C., Dubuisson, J., Monk, P., Higginbottom, A., Levy, S.,McKeating, J.A., 1999. Characterization of hepatitis $\mathrm{C}$ virus $\mathrm{E} 2$ glycoprotein interaction with a putative cellular receptor, CD81. Journal of Virology 73, 6235-6244. 
1 Garnier, J., Gibrat, J.-F.,Robson, B., 1996. GOR method for predicting protein secondary structure from amino acid sequence, in: R.F.E. Doolittle (Ed), Methods in Enzimology, Vol. 266.pp. 540-553.

Goffard, A., Callens, N., Bartosch, B., Wychowski, C., Cosset, F.L., Montpellier, C.,Dubuisson, J., 2005. Role of N-linked glycans in the functions of hepatitis C virus envelope glycoproteins. J. Virol. 79, 8400-8409.

Goffard, A.,Dubuisson, J., 2003. Glycosylation of hepatitis C virus envelope proteins. Biochimie 85, 295-301.

Habersetzer, F., Fournillier, A., Dubuisson, J., Rosa, D., Abrignani, S., Wychowski, C., Nakano, I., Trépo, C., Desgranges, C.,Inchauspé, G., 1998. Characterization of human monoclonal antibodies specific to the hepatitis $\mathrm{C}$ virus glycoprotein E2 with in vitro binding neutralization properties. Virology 249, 32-41.

Helenius, A.,Aebi, M., 2001. Intracellular functions of N-linked glycans. Science 291, 2364-9.

Helle, F., Goffard, A., Morel, V., Duverlie, G., McKeating, J., Keck, Z.Y., Foung, S., Penin, F., Dubuisson, J., Voisset, C., 2007. The neutralizing activity of antihepatitis $\mathrm{C}$ virus antibodies is modulated by specific glycans on the E2 envelope protein. J. Virol. 81, 8101-8111.

Hijikata, M., Kato, N., Ootsuyama, Y., Nakagawa, M., Ohkoshi, S.,Shimotohno, K., 1991. Hypervariable regions in the putative glycoprotein of hepatitis C virus. Biochem Biophys Res Commun 175, 220-8.

Hsu, H.H., Donets, M., Greenberg, H.B.,Feinstone, S.M., 1993. Characterization of hepatitis $\mathrm{C}$ virus structural proteins with a recombinant baculovirus expression system. Hepatology 17, 763-71. 
1 Hsu, M., Zhang, J., Flint, M., Logvinoff, C., Cheng-Mayer, C., Rice,

C.M.,McKeating, J.A., 2003. Hepatitis C virus glycoproteins mediate pHdependent cell entry of pseudotyped retroviral particles. P. N. A. S. USA 100, $7271-7276$.

Hu, Y.W., Rocheleau, L., Larke, B., Chui, L., Lee, B., Ma, M., Liu, S., Omlin, T., Pelchat, M.,Brown, E.G., 2005. Immunoglobulin mimicry by hepatitis C virus envelope protein E2. Virology 332, 538-549.

Hüssy, P., Faust, H., Wagner, J.-C., Schmid, G., Mous, J.,Jacobsen, H., 1997. Evaluation of hepatitis $\mathrm{C}$ virus envoloped proteins expressed in E. coli and insect cells for use as tools for antibody screening. J. Hepatol. 26, 1179-1186.

Hüssy, P., Schmid, G., Mous, J.,Jacobsen, H., 1996. Purification and in vitrophospholabeling of secretory envelope proteins E1 and E2 of hepatitis C virus expressed in insect cells. Virus research 45, 45-57.

Kato, N., Ootsuyama Y, Tanaka T, Nakagawa M, Nakazawa T, Muraiso K, Ohkoshi S, Hijikata M,K.., S., 1992. Marked sequence diversity in the putative envelope proteins of hepatitis C viruses. Virus Research. 22, 107-123.

Laemmli, V.K., 1970. Cleavage of structural proteins during the assembly of the head of bacteriophage T4. Nature 227, 680-685.

Lambot, M., Fretier, S., De Beeck, A.O., Quatannens, B., Lestavel, S., Clavey, W.,Dubuisson, J., 2002. Reconstitution of hepatitis C virus envelope glycoproteins into liposomes as a surrogate model to study virus attachment. J. Biol. Chem. 277, 20625-20630.

Lehrer, S.S., 1971. Solute perturbation of protein fluorescence. The quenching of the tryptophyl fluorescence of model compounds and of lysozyme by iodide ion. Biochemistry 10, 3254-63. 
1 Lindenbach, B.D., Rice, C.M., 2001. Flaviridae: The Viruses and Their Replication., in: Knipe, D., Howley, P.M. (Eds), Fields Virology. Lippincott Williams \& Wilkins, Philadelphia. pp. 41.

Major, M.E., Rehermann, B.,Feinstone, S.M., 2001. Hepatitis C viruses, in: Knipe, D., Howley, P.M. (Eds), Fields Virology. Lippincott Williams \& Wilkins, Philadelphia. pp. 1.

Martinez-Donato, G., Acosta-Rivero, N., Morales-Grillo, J., Musacchio, A., Vina, A., Alvarez, C., Figueroa, N., Guerra, I., Garcia, J., Varas, L., Muzio, V.,Duenas-Carrera, S., 2006. Expression and processing of hepatitis C virus structural proteins in Pichia pastoris yeast. Biochem. Biophys. Res. Comm. $342,625-631$.

Matsuo, E., Tani, H., Komoda, Y., Okamoto, T., Miyamoto, H., Moriishi, K., Yagi, S., Patel, A.H., Miyamura, T.,Matsuura, Y., 2006. Characterization of HCVlike particles produced in a human hepatoma cell line by a recombinant baculovirus. Biochem. Biophys. Res. Comm. 340, 200-208.

Matsuura, Y., Harada, S., Suzuki, R., Watanabe, Y., Inoue, Y., Saito, I.,Miyamura, T., 1992. Expression of processed envelope protein of hepatitis $\mathrm{C}$ virus in mammalian and insect cells. J Virol 66, 1425-31.

Michalak, J.-P., Wychowski, C., Choukhi, A., Meunier, J.-C., Ung, S., Rice, C.M.,Dubuisson, J., 1997. Characterization of truncated forms of hepatitis C virus glycoproteins. J. Gen.Virol. 78, 2299-2306.

Op De Beeck, A., Cocquerel, L.,Dubuisson, J., 2001. Biogenesis of hepatitis C virus envelope glycoproteins. J. Gen. Virol. 82, 2589-2595.

Owsianka, A., Clayton, R.F., Loomis-Price, L.D., McKeating, J.A.,Patel, A.H., 2001. Functional analysis of hepatitis C virus E2 glycoproteins and virus-like 
particles reveals structural dissimilarities between different forms of E2. J. Gen. Virol. 82, 1877-1883.

Patel, A.H., Wood, J., Penin, F., Dubuison, J.,McKeating, J.A., 2000. Construction and characterization of chimeric hepatitis $\mathrm{C}$ virus $\mathrm{E} 2$ glycoproteins: analysis of regions critical for glycoprotein aggregation and CD81 binding. J. Gen. Virol. 81, 2873-2883.

Perczel, A., Hollósi, M., Tusnády, G.,Fasman, G.D., 1991. Decovolution of the circular dichroism spectra of proteins: The circular dichroism spectra of antiparallel -sheet in proteins. Protein Eng 4, 669-679.

Pileri, P., Uematsu, Y., Campagnoli, S., Galli, G., Falugi, F., Petracca, R., Weiner, A.J., Houghton, M., Rosa, D., Grandi, G.,Abrignani, S., 1998. Binding of hepatitis C virus to CD81. Science 282, 938-941.

Ralston, R., Thudium, K., Berger, K., Kuo, C., Gervase, B., Hall, J., Selby, M., Kuo, G., Houghton, M.,Choo, Q.L., 1993. Characterization of hepatitis C virus envelope glycoprotein complexes expressed by recombinant vaccinia viruses. J. Virol. 67, 6753-61.

Schuck, P., 2000. Size-distribution analysis of macromolecules by sedimentation velocity ultracentrifugation and lamm equation modeling. Biophys J. 78, 1606-1609.

Shimizu, Y.K., Igarashi, H., Kiyohara, T., Cabezon, T., Farci, P., Purcell, R.H.,Yoshikura, H., 1996. A hyperimmune serum against a synthetic peptide corresponding to the hypervariable region 1 of hepatitis $\mathrm{C}$ virus can prevent viral infection in cell cultures. Virology 223, 409-12.

van Ree, R., Cabanes-Macheteau, M., Akkerdaas, J., Milazzo, J.P., LoutelierBourhis, C., Rayon, C., Villalba, M., Koppelman, S., Aalberse, R., Rodriguez, R., Faye, L.,Lerouge, P., 2000. Beta(1,2)-xylose and alpha(1,3)- 
fucose residues have a strong contribution in IgE binding to plant glycoallergens. J. Biol. Chem. 275, 11451-8.

Wakita, T., Pietschmann, T., Kato, T., Date, T., Miyamoto, M., Zhao, Z., Murthy, K., Habermann, A., Krausslich, H.G., Mizokami, M., Bartenschlager, R.,Liang, T.J., 2005. Production of infectious hepatitis $\mathrm{C}$ virus in tissue culture from a cloned viral genome. Nat. Med. 11, 791-6.

Wellnitz, S., Klumpp, B., Barth, H., Ito, S., Depla, E., Dubuisson, J., Blum, H.E.,Baumert, T.F., 2002. Binding of hepatitis C virus-like particles derived from infectious clone H77C to defined cell lines. J.Virol. 76, 1181-1193.

Xiang, Z.H., Cai, W.J., Zhao, P., Kong, L.B., Ye, L.B.,Wu, Z.H., 2006. Purification and application of bacterially expressed chimeric protein E1E2 of hepatitis C virus. Protein Expression and Purification 49, 95-101.

Yagnik, A.T., Lahm, A., Meola, A., Roccasecca, R.M., Ercole, B.B., Nicosia, A.,Tramontano, A., 2000. A model for the hepatitis C virus envelope glycoprotein E2. Proteins: structure, function, and genetics 40, 355-366.

Yurkova, M.S., Patel, A.H.,Fedorov, A.N., 2004. Characterisation of bacterially expressed structural protein E2 of hepatitis C virus. Protein Expression and Purification 37, 119-125.

Zhang, J., Randall, G., Higginbottom, A., Monk, P., Rice, C.M.,McKeating, J.A., 2004a. CD81 is required for hepatitis C virus glycoprotein-mediated viral infection. J. Virol. 78, 1448-1455.

Zhang, M., Gaschen, B., Blay, W., Foley, B., Haigwood, N., Kuiken, C.,Korber, B., 2004b. Tracking global patterns of N-linked glycosylation site variation in highly variable viral glycoproteins: HIV, SIV, and HCV envelopes and influenza hemagglutinin. Glycobiology 14, 1229-46. 
1 Zhong, J., Gastaminza, P., Cheng, G.F., Kapadia, S., Kato, T., Burton, D.R., Wieland, S.F., Uprichard, S.L., Wakita, T.,Chisari, F.V., 2005. Robust hepatitis C virus infection in vitro. P.N.A.S. USA 102, 9294-9299.

4 Zibert, A., Kraas, W., Ross, R.S., Meisel, H., Lechner, S., Jung, G.,Roggerdorf, M., 1999. Immunodominant B-cell domains of hepatitis C virus envelope proteins

6 E1 and E2 identified during early and late time points of infection. J. Hepatol. $30,177-184$.

8 


\section{$1 \quad$ Figure captions}

3 Fig. 1. Oligomeric nature of $\mathbf{E 2} \mathbf{6 6 1}_{66}$. The purified $E 2_{661}$ was subjected to SDS-

4 PAGE in the presence (lane 1) and in the absence (lane 2) of reducing agent. (P)

5 Protein size markers. (a) monomer, (b) dimer, (c) trimer and (d) tetramer. The gel

6 was stained with Coomassie Brilliant blue R-250.

8 Fig. 2. Sedimentation velocity analysis of $\mathbf{E 2}_{\mathbf{6 6 1}}$. The results are shown as the

9 sedimentation coefficient distribution $c(s)$. The experiment was carried out at 5 $10 \mu \mathrm{M}$ native $\mathrm{E} 2661$. 
1 Near-UV CD spectrum of E2 $2_{661}$ at $\mathrm{pH}$ 7.0. The pathlength of the cuvette was 0.5

$2 \mathrm{~cm}$ and the protein concentration was $0.5 \mathrm{mg} / \mathrm{ml}$. The buffer was MOPS $30 \mathrm{mM}$,

$3 \mathrm{pH} 7.0,100 \mathrm{mM} \mathrm{NaCl}$. Both spectra were recorded five times, averaged and

4 corrected for buffer contributions. Data were collected at $25{ }^{\circ} \mathrm{C}$ and are expressed

5 as residue molar ellipticity.

6

7 Fig. 5. Fluorescence emission spectra of E2 $\mathbf{6 6 1}_{66}$. The excitation wavelength was $8275 \mathrm{~nm}(-)$ and $295 \mathrm{~nm}(---)$. The emission spectra were recorded between 300 9 and $450 \mathrm{~nm}$. The spectrum obtained after excitation at $295 \mathrm{~nm}$ was normalized at 10 wavelengths above $380 \mathrm{~nm}$. The contribution of Tyr residues (•••) to the emission 11 spectrum was calculated as described in the Materials and Methods section. 12 Protein concentration was $0.05 \mathrm{mg} / \mathrm{ml}$. The buffer was sodium phosphate $20 \mathrm{mM}$, buffer was always subtracted. 
1 Materials and Methods section. Eight HCV-positive human sera (1-8) and ten HCV-

2 negative human sera were used at a dilution of 1:200. Only the results obtained with

3 two negative controls ( 9 and 10) are shown since all of them gave virtually the same

4 optical density. Bound antibodies were detected with peroxidase conjugated anti-

5 human $\operatorname{IgG}(\mathrm{Fc})$ diluted at 1:10000. The lower part shows the results of the Western

6 blot analysis after electrophoresis in the presence of SDS and $\beta$-mercaptoethanol.

7 The nitrocellulose membranes which were incubated with individual sera from HCV-

8 positive and negative patients at a dilution of 1:20, were developed with peroxidase-

9 conjugate goat anti-human IgG diluted at 1:1000 and E2 661 was detected with ECL

10 detection reagents. 
Table 1

Tryptic peptides of native E2 ${ }_{661}$ recombinant protein identified by SELDI5 TOF and MALDI-TOF MS.

\begin{tabular}{|c|c|c|}
\hline \multicolumn{3}{|c|}{ SELDI-TOF } \\
\hline Molecular Mass $^{\mathrm{a}}$ & Peptide $^{b}$ & Position $^{\mathrm{c}}$ \\
\hline 750.110 & CNLEDR & $278-283$ \\
\hline 961.520 & HPEATYSR & $215-222$ \\
\hline 1021.260 & CNLEDRDR & $278-285$ \\
\hline 1028.580 & CLVNYPYR & $233-240$ \\
\hline 1048.550 & MYVGGVEHR & $257-265$ \\
\hline 1064.540 & LEAACNWTR & $266-274$ \\
\hline 1074.560 & CGSGPWITPR & $223-232$ \\
\hline 1089.850 & KHPEATYSR & $214-222$ \\
\hline 1800.030 & LWHYPCTINYTIFK & $241-254$ \\
\hline 2092.400 & MYVGGVEHRLEAACNWTR & $257-274$ \\
\hline 2184.610 & SVCGPVYCFTPSPVVVGTTDR & $127-147$ \\
\hline 2531.800 & VCGAPPCVIGGVGNNTLHCPTDCFR & $189-213$ \\
\hline 2659.660 & VCGAPPCVIGGVGNNTLHCPTDCFRK & $189-214$ \\
\hline 2809.090 & CLVNYPYRLWHYPCTINYTIFK & $233-254$ \\
\hline 3474.510 & $\begin{array}{l}\text { ADPHHHHHHETHVTGGTAAQTTAGLVSLLSPG } \\
\text { AK }\end{array}$ & $1-34$ \\
\hline 4347.460 & $\begin{array}{l}\text { QDIQLINTNGSWHINSTALNCNDSLYTGWLAGL } \\
\text { FYHHK }\end{array}$ & $35-72$ \\
\hline \multicolumn{3}{|c|}{ MALDI-TOF } \\
\hline 996.420 & FNSSGCPER & $73-81$ \\
\hline 1028.580 & CLVNYPYR & $233-240$ \\
\hline 1048.550 & MYVGGVEHR & $257-265$ \\
\hline 1064.540 & LEAACNWTR & $266-274$ \\
\hline 1074.560 & CGSGPWITPR & $223-232$ \\
\hline 2092.400 & MYVGGVEHRLEAACNWTR & $257-274$ \\
\hline 2184.610 & SVCGPVYCFTPSPVVVGTTDR & $127-147$ \\
\hline 2531.800 & VCGAPPCVIGGVGNNTLHCPTDCFR & $189-213$ \\
\hline
\end{tabular}

6

$7 \quad{ }^{\mathrm{a}}$ The molecular mass corresponds to the experimental value. ${ }^{\mathrm{b}}$ The cysteine residues are

8 shown in bold. ${ }^{\mathrm{c}}$ The numbers indicate the position of the aminoacid in the cloned protein. 
Table 2

2 Secondary structure of $\mathbf{E} \mathbf{2}_{661}$.

3

\begin{tabular}{ccc}
\hline \% & Experimental $^{\mathbf{a}}$ & Theoretical $^{\mathbf{b}}$ \\
\hline$\alpha$-helix & 8 & 2 \\
$\beta \square$-sheet & 47 & 34 \\
Non-ordered & 45 & 64 \\
\hline
\end{tabular}

6

$7{ }^{a}$ The experimental values were calculated from the far-UV CD spectrum by using the 8 deconvolution program CCA (Perczel et al., 1991). ${ }^{\text {b }}$ The theoretical values were calculated 9 by GOR IV method (Garnier et al., 1996). 
Figure 1

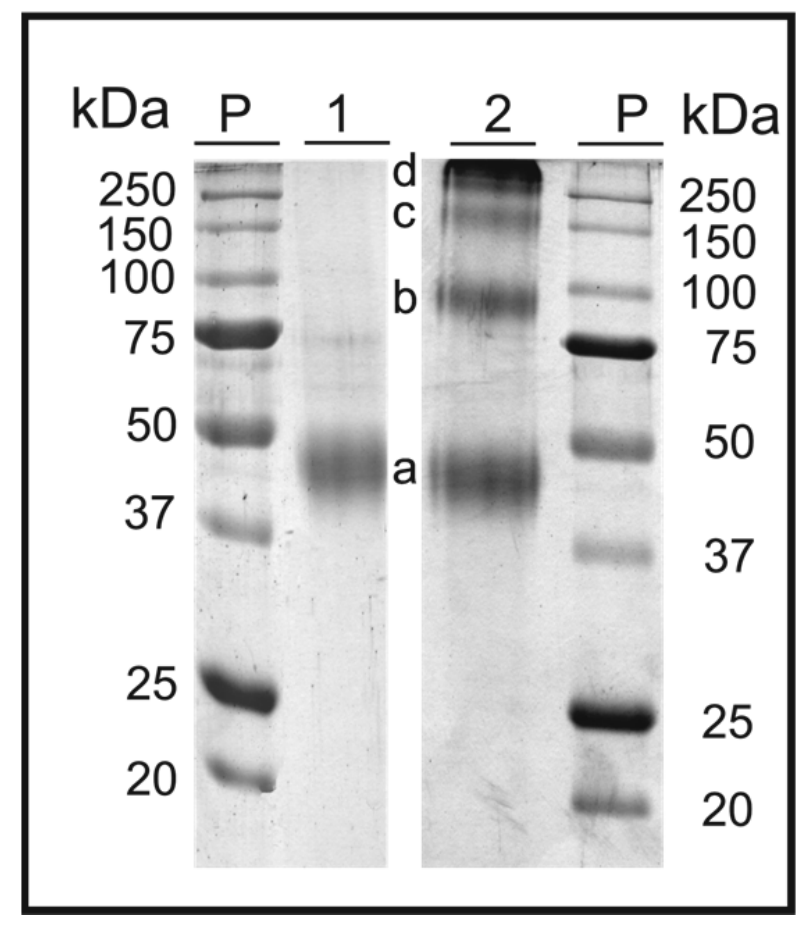

Figure 2

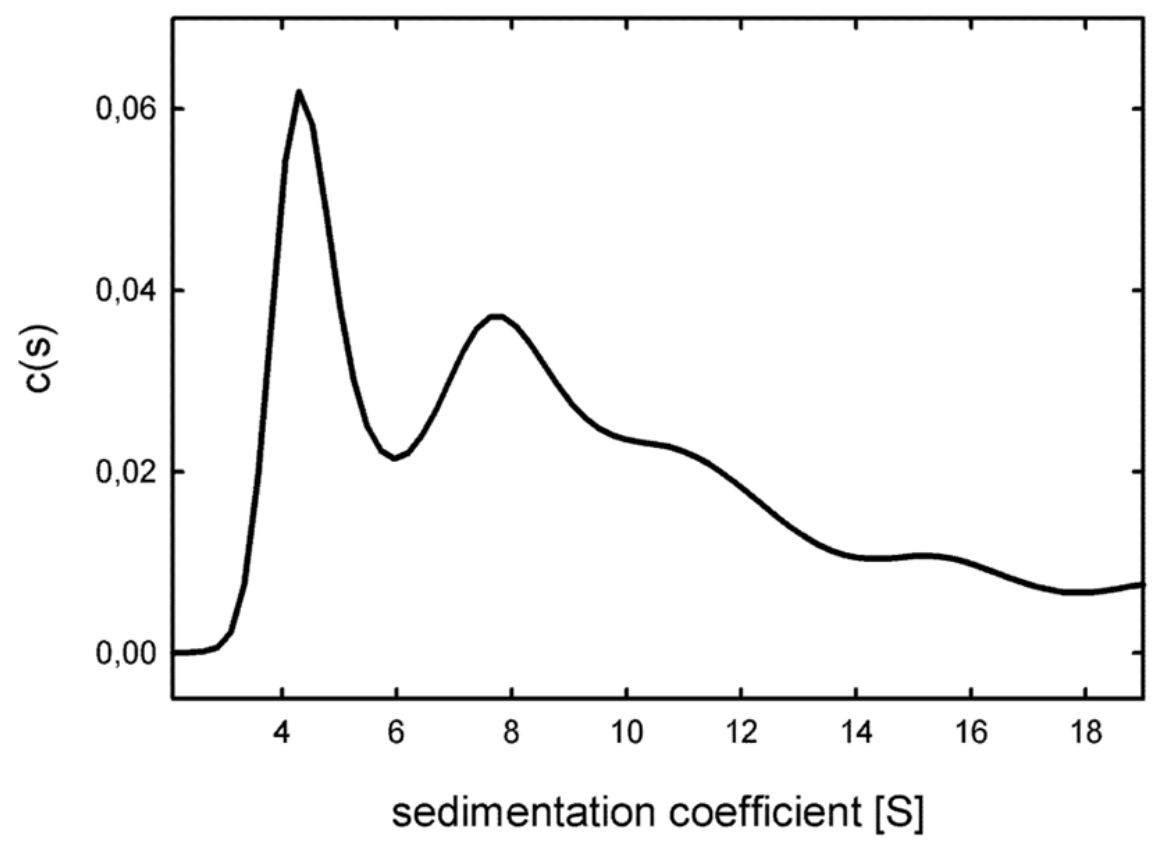


Figure 3

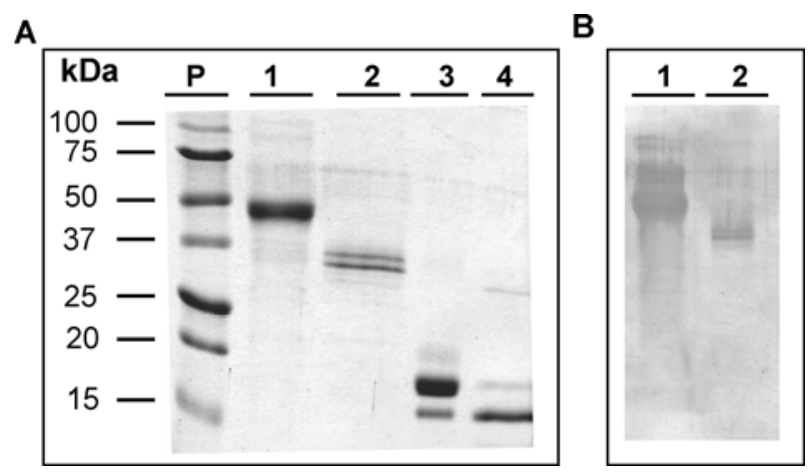

Figure 4
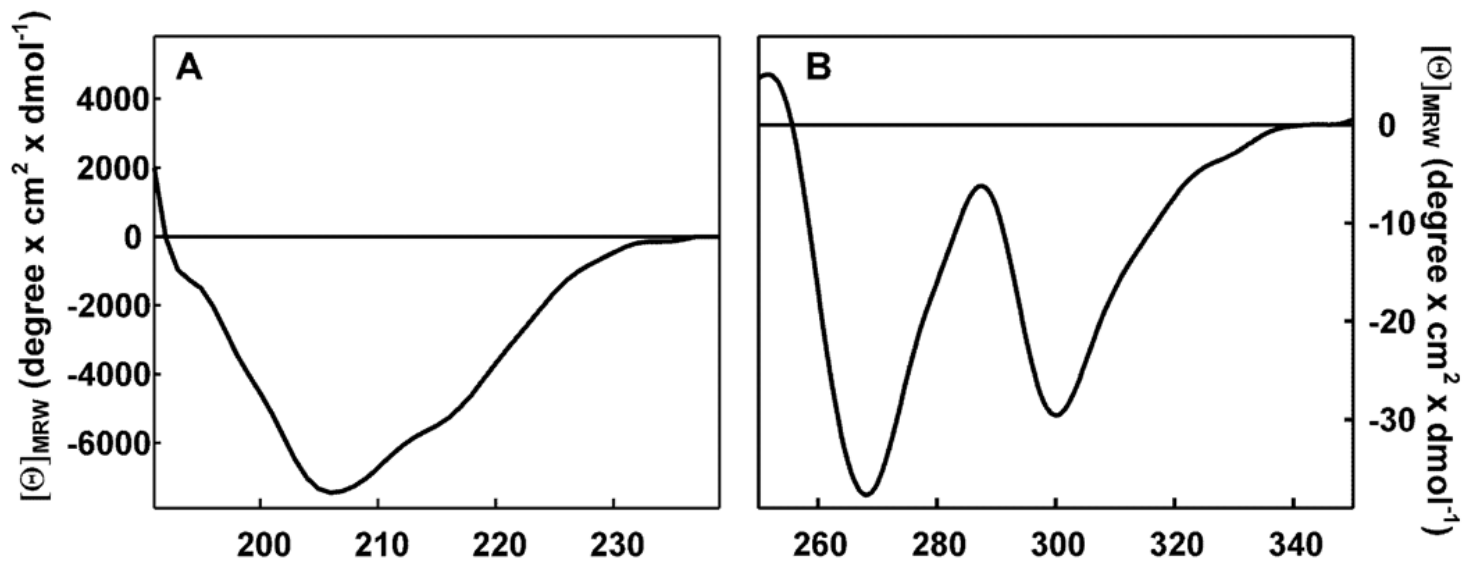

Wavelength (nm) 
Figure 5

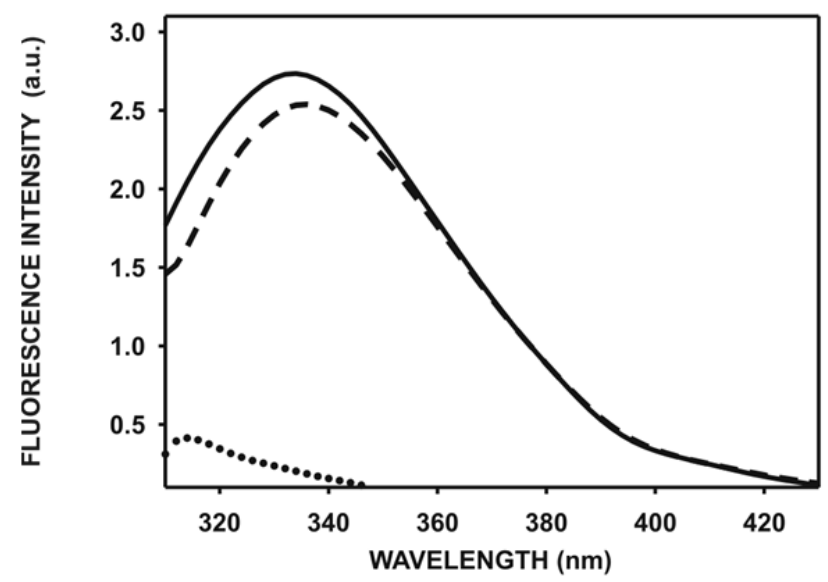

Figure 6

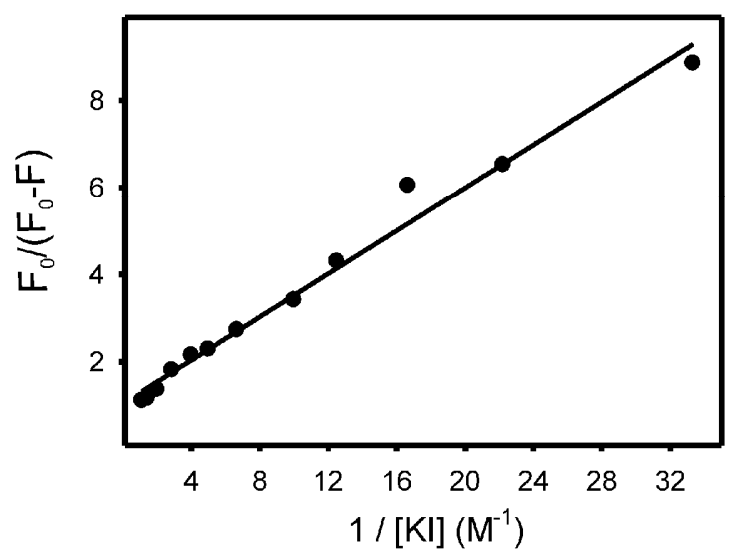


Figure 7

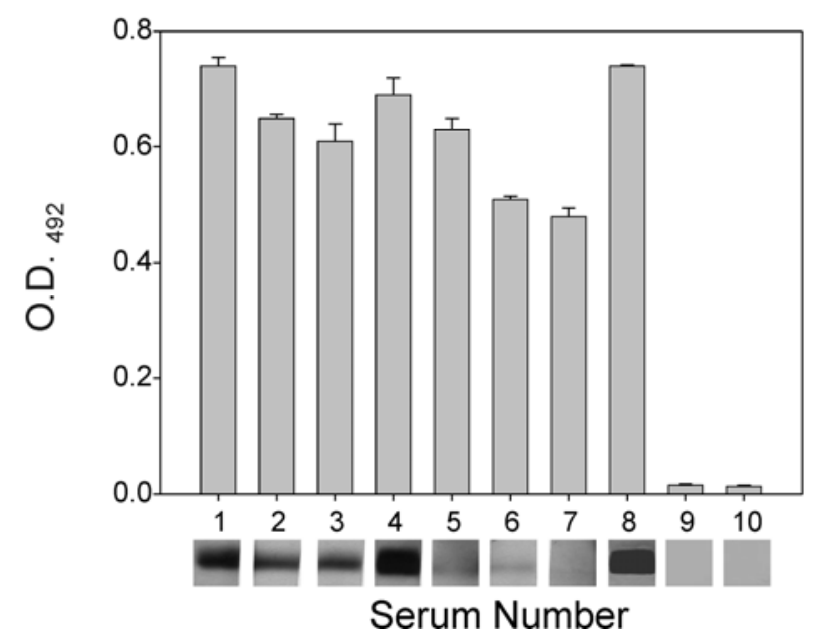

